[Radiocarbon, Vol. 13, No. 2, 1971, P. 395-411]

\title{
UNIVERSITY OF ROME CARBON-14 DATES IX
}

M. ALESSIO, F. BELLA, S. IMPROTA,

Istituto di Fisica, Università di Roma

\section{G. BELLUOMINI, C. CORTESI, and B. TURI}

Istituto di Geochimica, Università di Roma

This list includes age measurements carried out from November 1969 to December 1970. All archaeologic and geologic samples come from Italian territory. Laboratory equipment, largely unchanged, has been described (Alessio et al., 1970).

The activity of our "modern standard", wood grown near Rome between 1949 and 1953, was checked with 95\% of the counting rate of NBS oxalic acid and measurements were found coincident within $1 \sigma$. For each sample of $\mathrm{CO}_{2}$, the counting rate was corrected according to mass-spectrometrically measured $\mathrm{C}^{13} / \mathrm{C}^{12}$ ratio as described previously (Alessio et al., 1969). Age was calculated using the Libby half-life of $5568 \pm 30 \mathrm{yr}$, with 1950 as the standard year of reference.

\section{ACKNOWLEDGMENTS}

We thank the Consiglio Nazionale delle Ricerche for providing partial financial support. We also thank G. Calderoni for his valuable work in sample preparation, and our technicians for their assiduous, fine work: A. Fruscalzo in mass-spectrometric measurements and B. Petrocchi in activity measurements.

\section{SAMPLE DESCRIPTIONS}

I. ARCHAEOLOGIC AND HISTORIC SAMPLES

$$
\text { A. Italy }
$$

\section{R-667. Lagazzi}

Charcoal from inside some vases with original filling from excavations done 1890-1891 at lake dwelling of Lagazzi, between Vho and $\mathrm{S}$. Lorenzo Guazzone, prov. Cremona, Lombardy $\left(45^{\circ} 06^{\prime} 25^{\prime \prime} \mathrm{N}\right.$ Lat, $10^{\circ}$ $23^{\prime} 25^{\prime \prime}$ E Long) and since housed in Mus. Civico of Cremona. Coll. 1967 by G. Ciremonesi, Ist. di Paletnol., Univ. of Lecce and subm. 1969 by A. M. Radmilli, Ist. Antropol. e Paleontol. Umana, Univ. of Pisa. Lagazzi lake dwelling is attributable to Bronze age with strong influence from Polada culture (Parazzi, 1891; Cremonesi, 1967). Comment: charcoal from vases numbered 12, 18, 25, 36, 40, and 150 and from one unnumbered vase. Late Bronze age is acceptable.

\section{R-700 $\alpha$. Monte Madarosa}

Charcoal from prehistoric open-air settlement along $\mathrm{NE}$ side of Monte Madarosa, a basaltic hill, $561 \mathrm{~m}$, forming part of the divide between Chiampo and Alpone valleys, $2 \mathrm{~km}$ SSW Chiampo, prov. Verona, 
Veneto (45 31' 33" N Lat, $11^{\circ} 16^{\prime} 10^{\prime \prime} \mathrm{E}$ Long). Coll. 1960 and subm. 1970 by A. Menin. Archaeol. deposit, evidenced by plentiful flint implements, pottery, and bones, was widely disarranged. Charcoal from undisturbed carbonaceous lens at $1.5 \mathrm{~m}$ depth, ca. $40 \mathrm{~m}$ from hilltop, containing only arrow-heads. Comment: Monte Madarosa pottery is attributable to middle and late phases of Bronze age; only a few elements can be attributed to early and final Bronze age phases. Cultural complex belongs to Berico-Euganea facies, featured by strong influences from central and $\mathrm{S}$ Italian cultures. At Madarosa settlement, typical specimens of Apennines culture are present (L. Fasani, pers. commun.). Date is late Bronze age.

\section{R-358. Lago di Ledro}

$\mathbf{3 3 5 0} \pm \mathbf{5 0}$ 1400 B.C.

Well-preserved wood from wooden pile of large lake dwelling settlement of Bronze age in Ponale effluent area, near Molina di Ledro, Ledro lake, prov. Trento (45 $52^{\prime} 30^{\prime \prime} \mathrm{N}$ Lat, $10^{\circ} 45^{\prime} 40^{\prime \prime}$ E Long). Coll. 1955 and subm. 1967 by O. Cornaggia Castiglioni, Sopr. Monumenti, Milan. Comment: pottery of Polada culture was found at Ponale lake settlement (Battaglia, 1943). R-358 date is practically identical with preceding one measured on charcoal by Rome Lab.: R-7, $3310 \pm 210$ (R., 1964, v. 6, p. 82); part of other wooden pile dated at Pisa: Pi-88, $3137 \pm 105$ (R., 1961, v. 3, p. 102); wooden beam dated at Birmingham: Birm-34, $3659 \pm 66$ and $3642 \pm 36$ (R., 1968, v. 10, p. 205). Available dates attributed to Polada culture in lake dwellings scattered in Po Plain reported by Alessio et al. (R., 1967, v. 9, p. 349), and discussed by both O. Cornaggia Castiglioni (1967) and Barfield (1968).

\section{R-506 $\alpha$. Lago Fimon}

$$
\begin{array}{r}
\mathbf{2 8 0} \pm \mathbf{5 0} \\
\text { A.D. } 1670
\end{array}
$$$$
\delta \mathrm{C}^{13}=-24.2 \%
$$

Darkened wood, from wooden post, found on $\mathrm{E}$ shore of Fimon Lake, Berici Mts. ca. $9 \mathrm{~km} \mathrm{~S} \mathrm{Vicenza,} \mathrm{Veneto}\left(45^{\circ} 28^{\prime} 20^{\prime \prime} \mathrm{N}\right.$ Lat, $11^{\circ}$ 32' 43" E Long). Coll. by G. Barioli, Mus. Civici Vicenza; subm. by T. Mantovani. Comment: a few other posts were embedded in mud in same area; $\mathrm{C}^{14}$ date indicates a relatively modern structure not belonging to prehistoric lake dwelling of Fimon Lake.

R-608. Ancarano di Sirolo E

$3140 \pm 60$

1190 B.C.

$\delta \mathrm{C}^{13}=-25.3 \%$

R-608 $\alpha$. Ancarano di Sirolo E

$3100 \pm 60$

1150 B.C.

$\delta \mathrm{C}^{13}=-25.6 \%$

$\mathbf{3 1 9 0} \pm \mathbf{5 0}$

R-608 $\alpha / 1$. Ancarano di Sirolo E

1240 B.C.

$\delta \mathrm{C}^{13}=-25.8 \%$ o

Charcoal from Zone $\mathrm{E}$ of prehistoric open-air settlement at Con- 
trada Ancarano, ca. $1.5 \mathrm{~km}$ SW Sirolo, prov. Ancona, Marche $\left(43^{\circ} 30^{\prime}\right.$ $46^{\prime \prime} \mathrm{N}$ Lat, $13^{\circ} 36^{\prime} 18^{\prime \prime} \mathrm{E}$ Long). Coll. 1961 and subm. 1969 by D. G. Lollini, Sopr. Antichità Marche. Excavations revealed a single cultural horizon under soil; few flint implements and pottery, the latter with some features in common with Bronze age lake dwelling cultures scattered on Po plain (Lollini, 1961). Comment: R-608 was given $5 \% \mathrm{HCl}$ pretreatment only; R-608 $\alpha$ and $\mathrm{R}-608 \alpha_{1}$, separately, were given additional leaching with $6 \% \mathrm{NH}_{4} \mathrm{OH}$; all dates are consistent and show abundant humic fraction removed was not contaminating. Age rather younger than expected.

\section{Ripoli series}

In 1960-65 new excavations were made at large Neolithic village of Ripoli, left side of Vibrata R. valley, prov. Teramo, Abruzzi $\left(42^{\circ}\right.$ $49^{\prime} 30^{\prime \prime}$ N Lat, $13^{\circ} 33^{\prime} 23^{\prime \prime}$ E Long). Typologic characteristics of Ripoli culture, placed in the Middle and Upper Neolithic, were better identified and, based on different frequency of elements and categories of pottery in various huts and presence of sherds of imported pottery, different phases in development of Ripoli culture and village were determined (Cremonesi, 1965). Charcoal from Huts 6 and 12 coll. 196264 by G. Cremonesi and subm. 1969 by A. M. Radmilli.

\section{R-665. Ripoli 6}

$5560 \pm 150$

3610 B.C.

$\delta \mathrm{C}^{13}=-24.7 \%$

Charcoal from Hut 6, far E side of village. Comment: from type of material, Hut 6 may be attributed to an intermediate stage of settlement. Date agrees with cultural stage.

\section{R-664. Ripoli 12}

$5630 \pm 80$ 3680 B.C.

$$
\delta \mathrm{C}^{13}=-25.0 \%
$$

Charcoal from Hut 12, far W side of so far explored village. Comment: Hut 12 is believed to belong to an early stage of village. Date agrees with cultural stage.

General Comment: Hut 3 of Ripoli village was dated by Pisa (unpub.): $5100 \pm 120$ (Cremonesi, 1965). Dates of other settlements with evidence of similar culture are: Grotta dei Piccioni, upper horizon, Pi-49, 4770 \pm 110 (R., 1961, v. 3, p. 100); Grotta Scaloria, trichrome pottery: R-349, $5480 \pm 70$ (R., 1969, v. 11, p. 485).

\section{R-614. Grifo, Perugia}

\section{A.D. 1150}

$800 \pm 80$

$\delta \mathrm{C}^{13}=-26.2 \%$

Very fine particles of carbonized organic matter in quartz-carbonate clay, forming core mold of a bronze gryphon statue decorating gate of Palazzo dei Priori in Perugia, Umbria; removed for restoration in 1966. 
Coll. and subm. 1969 by M. Marabelli, Ist. Centrale del Restauro, Rome. Comment: sample pretreatment with $8 \mathrm{~N} \mathrm{HCl}$. Organic matter used in making clay mold for bronze casting was both animal and vegetable (wool cloth clippings, carding wool waste, animal hair, dung, cut straw, and leaves, etc.) (Theophilus, 1140?; Vannoccio Biringuccio, 1540; Cellini, 1568; Vasari, 1568). Carbonized material in core mold of Gryphon, ca. $3.5 \%$ in weight, id. as very fine vegetable particles by $M$. Follieri, Ist. Botanica, Univ. of Rome (pers. commun.); chemical and mineralogic analyses of clay core were done by M. Marabelli (1971). Dated because of divergent opinions of age of Gryphon, believed Etruscan by one scholar (Caputo, 1961) and Mediaeval by most experts. Age confirms the latter.

\section{R-683. Baia}

$1570 \pm 50$

\section{A.D. 380}

$\delta \mathbf{C}^{13}=-26.5 \%$

Well-preserved wood (Larix sp.) id. by M. Follieri (pers. commun.), wooden plank fragment belonging to ancient harbor structure, palisade $20 \mathrm{~m}$ long, water depth $4.5 \mathrm{~m}$, in Baia archaeol. area, Pozzuoli Gulf, prov. Naples ( $40^{\circ} 49^{\prime} 03^{\prime \prime} \mathrm{N}$ Lat, $14^{\circ} 04^{\prime} 34^{\prime \prime}$ E Long). Coll. 1968 and subm. 1969 by P. Colantoni, Lab. Geol. Marina C.N.R., Bologna. Comment: date confirms expected Roman origin.

\section{B. Elba Island}

\section{Golfo di Procchio shipwreck series}

1969 excavations in Procchio Gulf, N coast of Elba I. (42 $47^{\prime} 31^{\prime \prime}$ $\mathrm{N}$ Lat, $10^{\circ} 14^{\prime} 56^{\prime \prime} \mathrm{E}$ Long), water depth ca. $1.90 \mathrm{~m}$, revealed partially preserved wooden ship, ca. $20 \mathrm{~m}$ long, buried in sandy sediments at depth ca. $40 \mathrm{~cm}$. Wood coll. 1969 by A. Fioravanti and subm. 1969 by L. Ferri-Ricchi.

\section{R-678. Golfo di Procchio Wreck 1}

$1610 \pm 50$

\section{A.D. 340}

Wood from longitudinal structure of ship, level with keelsons.

\section{R-679. Golfo di Procchio Wreck 2}

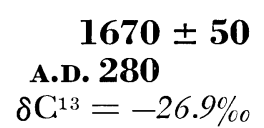

Wood (Quercus cfr. ilex) id. by M. Follieri (pers. commun.) found inside ship, but apparently unconnected with structure.

General Comment: wreck, in view of nature and type of objects inside (amphoras, lamps, glass goblets, etc.) was id. as imperial-age Roman merchant ship (Ferri-Ricchi, 1969; Fioravanti, 1970). Date confirms this.

Hitherto several shipwrecks from sunken ships found at various places along Italian, French, and Sardinian coasts have been dated at Univ. of Pennsylvania Lab. (R., 1966, v. 8, p. 353-355; 1970, v. 12, p. 585). 
R-609. Grotta del Guano

\section{R-609 $\alpha$. Grotta del Guano}

$$
\begin{gathered}
\mathbf{4 8 3 0} \pm \mathbf{5 0} \\
\mathbf{2 2 8 0} \text { в.c. } \\
\delta \mathrm{C}^{13}=-23.1 \% \circ \\
\mathbf{4 9 0 0} \pm \mathbf{5 0} \\
\mathbf{2 2 5 0} \text { B.C. } \\
\delta \mathrm{C}^{13}=-23.6 \% \circ
\end{gathered}
$$

Charcoal from lower level of deposit under thick calcareous stalagmitic horizon near $\mathrm{N}$ wall of central chamber of Grotta del Guano or di Gonogùsola, kartz cave in mesozoic limestone, right side of Cedrino R., Oliena, prov. Nuoro ( $40^{\circ} 17^{\prime} 15^{\prime \prime} \mathrm{N}$ Lat, $9^{\circ} 30^{\prime} 28^{\prime \prime} \mathrm{E}$ Long). Coll. 1961 by B. Piredda, Gruppo Speleol. Nuorese, and subm. 1968 by E. Castaldi, Ist. di Paletnol., Univ. of Rome. Pottery of S. Michele di Ozieri culture was found in deposit (Contu, 1964, 1966). Comment: R-609 received standard pretreatment with $5 \% \mathrm{HCl}$; R-609 $\alpha$ received additional leaching with $6 \% \mathrm{NH}_{4} \mathrm{OH}$ : 2 measurements were consistent, abundant humic fraction removed should not be regarded as contaminating but as belonging to humic charcoal. S. Michele culture is widespread throughout Sardinia in various settlements (huts, caves and shelters, rock-cut tombs or "domus de janas", etc.) (Lilliu, 1967; Bray, 1963; Ferrarese Ceruti, 1967; Contu, 1969) and it is thought to belong to Chalcolithic of Sardinia but, the culture being prolonged, it probably is even older (Atzeni, 1967; Pinna, 1966-1967). Date, oldest available for Sardinian prehistory, should confirm this opinion, placing S. Michele culture in Guano cave in Upper Neolithic (Castaldi, 1971).

S. Michele di Ozieri culture has some features similar to PeuRichard culture, which in some neolithic coastal settlements of CharenteMaritime, France, were dated from $2840 \pm 250$ to $2300 \pm 250$ B.c. (Thomas, 1965; Mohen, 1967; R., 1966, v. 8, p. 132; 1970, v. 12, p. 434435). Kidney-shaped earthenware loom-weights are a feature common both to S. Michele and Lagozza culture of Upper Neolithic of Po Plain, repeatedly dated at Rome and Pisa labs, ca. 3000-2800 B.c. (R., 1968, v. 10, p. 356-357; Guerreschi, 1967).

\section{Pantelleria Island}

\section{Mursia series}

Excavations were made during 1966-1968 in Bronze age village of Mursia, on rocky cliff between Cala di Modica and Cala dell'Alca, W coast of Pantelleria I. (36 $48^{\prime} 39^{\prime \prime} \mathrm{N}$ Lat, $11^{\circ} 54^{\prime} 41^{\prime \prime}$ E Long). Village consists of ellipsoidal stone huts and is protected inland by stone wall. Plentiful implements, mostly of obsidian, were found with pottery, largely atypical, making chronologic and cultural attribution of village difficult; however, an earlier phase was id. (Zone A, Huts 1, 2, 4, 5, and 6) and a later phase (Zone A, Hut 3), separated by an intermediate phase not yet fully distinguished (Radmilli, 1967; Tozzi, 1968). Charcoal from Huts 1, 3, and 4, Zone A of excavations, coll. 1966-67 by C. 
Tozzi and subm. 1969 by A. M. Radmilli. Samples were given 5\% HCl pretreatment; due to the presence of rootlets and humic fractions, $\alpha$ labeled samples were given additional leaching with $6 \% \mathrm{NH}_{4} \mathrm{OH}$.

\section{R-671. Mursia A, I-b, 7}

Charcoal from Zone A, Area I-b, Cut 7, lower stamped-earth floor of Hut 1. Comment: $\mathrm{C}^{14}$ date agrees with level belonging to earlier phase.

R-669 $\alpha$. Mursia A, I-be, 5

$2930 \pm 50$

980 B.C.

$\delta \mathrm{C}^{13}=-22.3 \%$ o

Charcoal from Zone A, Area I-bc, Cut 5, found at level of loosepebble foundation of upper stamped-earth floor of Hut 1. Comment: $\mathrm{C}^{14}$ age appears somewhat young; the hut might have been re-used in a more recent phase in village life, or sample might have been mixed with younger material during partial destruction of the hut a few years ago.

R-668 $\alpha$. Mursia A, IV-be, 4

$2990 \pm 50$

1040 B.C.

$\delta \mathrm{C}^{13}=-24.0 \%$

Charcoal from Zone A, Area IV-bc, Cut 4. Comment: $\mathrm{C}^{14}$ age is acceptable for late phase of village.

R-670 $\alpha$. Mursia A, V-c', 3-4

$3010 \pm 50$

1060 B.c.

$\delta \mathrm{C}^{13}=-24.6 \%$

Charcoal from Zone A, Area V-c', Cuts 3-4, in hearth of Hut 3. Comment: $\mathrm{C}^{14}$ can be accepted for Hut 3 belonging to late phase of village.

\section{R-673. Mursia A, IV-f', 3}

Charcoal from Zone A, Area IV-f', Cut 3, found inside a cist made of stone slabs in Hut 4. Comment: date appears too young: sample presumably got mixed with younger material.

\section{Valli Ferraresi}

\section{GEOLOGIC SAMPLES}

$$
\text { Italy }
$$

During reclamation of 2 littoral lagoon valleys in prov. of Ferrara, Mezzano and Giralda salt valleys, S area of Po R. delta, hundreds of subfossil stumps and trunks, relicts of ancient Adriatic littoral forest along Po banks, were found in situ in drained alluvium of valleys. Dated of some wood, id. by G. Cellai Ciuffi, Ist. Botan., Univ. of Florence (pers. commun.), were requested for palaeogeographic and palaeobotanic studies of region. 


\section{Valle del Mezzano series}

Wood, subfossil stumps and trunks, found in situ, Mezzano salt valley, between mouth of Primaro Po (Reno) and Volano Po, ca. $14 \mathrm{~km}$ W Comacchio, prov. of Ferrara, Emilia ( $40^{\circ} 42^{\prime} \mathrm{N}$ Lat, $12^{\circ} 02^{\prime} \mathrm{E}$ Long). Coll. by P. Stampi, Ist. Botan., Univ. of Ferrara, and subm. by E. Francini Corti, Ist. Botan., Univ. of Florence. Stumps and trunks covered large area and were partly buried at depth ca. $20 \mathrm{~cm}$ to $1 \mathrm{~m}$; latter discovered during tilling (Stampi, 1966).

\section{R-390. Valle del Mezzano 1}

$$
1460 \pm 60
$$

\section{A.D. 490}

$\delta \mathrm{C}^{13}=-29.1 \%$

Darkened wood (Populus sp.). Comment: sample was pretreated with $10 \% \mathrm{HCl}$ only because, despite darkening, test with $6 \% \mathrm{NH}_{4} \mathrm{OH}$ did not disclose humic material.

\section{R.391 $\alpha$. Valle del Mezzano 2}

$$
1890 \pm 50
$$

A.D. 60

$$
\delta \mathrm{C}^{13}=-27.3 \%
$$

Rather darkened wood (Betula sp.). Comment: sample was pretreated with $10 \% \mathrm{HCl}$ : no carbonate or $\mathrm{Fe}^{+++}$present, only abundant $\mathrm{Fe}^{++}$was detected, probably ferrous humate; additional leaching with $6 \% \mathrm{NH}_{4} \mathrm{OH}$ was given.

\section{R-392 $\alpha$. Valle del Mezzano 3}

$$
1620 \pm 50
$$

\section{A.D. 330}

$\delta \mathrm{C}^{13}=-29.5 \%$

Darkened wood (Populus sp.). Comment: sample was pretreated with $10 \% \mathrm{HCl}$ : no carbonate or $\mathrm{Fe}^{+++}$present, only abundant $\mathrm{Fe}^{++}$ was detected, probably ferrous humate; additional leaching with $6 \%$ $\mathrm{NH}_{4} \mathrm{OH}$ was given.

\section{R-393. Valle del Mezzano 4}

$$
1520 \pm 120
$$

\section{A.D. 430}

$\delta \mathrm{C}^{13}=-28.9 \%$

Slightly darkened wood (Alnus sp.). Comment: sample only pretreated with $10 \% \mathrm{HCl}$ : no carbonate, $\mathrm{Fe}^{+++}$and $\mathrm{Fe}^{++}$present; test with $6 \% \mathrm{NH}_{4} \mathrm{OH}$ did not reveal humic substances.

\section{R-394. Valle del Mezzano 5}

$1590 \pm 50$

\section{A.D. 360}

$\delta \mathrm{C}^{13}=-29.3 \%$

Well-preserved wood (Alnus sp.). Comment: sample pretreated with $10 \% \mathrm{HCl}$ only: no carbonate, $\mathrm{Fe}^{+++}$or $\mathrm{Fe}^{++}$present.

\section{R-395. Valle del Mezzano 6}

$$
\begin{array}{r}
\mathbf{1 5 1 0} \pm \mathbf{5 0} \\
\text { A.D. } 440 \\
\delta \mathrm{C}^{13}=-28.1 \% 0
\end{array}
$$

Well-preserved wood (Alnus sp.). Comment: sample pretreated with $10 \% \mathrm{HCl}$ only: no carbonate, $\mathrm{Fe}^{+++}$or $\mathrm{Fe}^{++}$present.

General Comment: no signs exist for reconstruction of original Mezzano 
salt valley and of Ferrara salt valleys, in general. It is certain, however, that shoals and banks emerged alternately, under vegetative cover, including forest, particularly of coastal type. Poplars and alders (Populus sp. and Alnus sp.), R-390, 392 $\alpha$, and 393-395 samples, dated A.D. 330-A.D. 490 , belong to coastal facies of Quercetum-Carpinetum vegetation, which characterized Po $R$. valley in Sub-Atlantic. The more microthermic birch (Betula sp.), R-391 $\alpha$, dated A.D. 60 may be regarded as relict of older forest vegetation, i.e., Quercetum with Abies and Alnus of SubBoreal. Evidence of such vegetation still exists in sheltered stations, e.g., in nearby Euganei Mts., whereas other areas have relicts of Mediterranean-type thermophilic and xerophilic vegetation (Lona, 1957; Marchesoni, 1959; Marchesoni and Paganelli, 1966; Govi, 1967; Montanari, 1969).

\section{Valle Giralda series}

Wood, subfossil (and modern) stumps and trunks thought to be found during reclamation of Giralda salt valley, between mouth of Volano Po and Goro Po, close to shoreline, ca. $15 \mathrm{~km} \mathrm{~N}$ Comacchio, prov. Ferrara, Emilia (44 $49^{\prime} \mathrm{N}$ Lat, 12 ${ }^{\circ} 10^{\prime} \mathrm{E}$ Long). Coll. 1964 in a wood lot by P. Stampi and subm. 1968 by E. Francini Corti. Samples in situ were very numerous, covered a large area, buried to ca. $1 \mathrm{~m}$ depth, and were discovered during tilling. Because of their abundance, stumps and trunks are used by local people for firewood (Stampi, 1966, and pers. commun.).

\section{R-386A. Valle Giralda 1}

\section{R-386. Valle Giralda 1}

$740 \pm 50$

\section{A.D. 1210}

$\delta \mathrm{C}^{13}=-26.4 \%$

$\mathbf{7 5 0} \pm \mathbf{5 0}$

\section{A.D. 1200}

$\delta \mathrm{C}^{13}=-27.4 \%$ pretreated, R-386 was pretreated with $10 \%$ HCl. Fagus sp. likely to oceanic and less microthermic character of Fagus, as compared to Betula, are still more frequent today and widespread in areas with Mediterranean vegetation. Ca. A.D. 1000, region's climate appears to have been favorable for a moderate local re-expansion of Fagus sp. (see refs. in Valle del Mezzano, General Comment).

R-387. Valle Giralda 2 ment.

Well-preserved wood (Quercus cfr. ilex). Comment: see R-389 Com-

\section{R-388. Valle Giralda 3} ment.

Well-preserved wood (Quercus cfr. ilex). Comment: see R-389 Com- 


\section{R-389A. Valle Giralda 4}

Well-preserved wood (Quercus sp. non ilex). Comment: R-389A was given no pretreatment; R-389 was given pretreatment with $10 \% \mathrm{HCl}$. Wood R-387 -389, believed subfossil, belong instead to present species from natural forests of region (Stampi, 1967). Sampling error occurred because samples were taken from wood pile at Bosco Mesola village, Giralda V., where reportedly exclusive subfossil wood coll. in preceding years in valley had been stored (Stampi, pers. commun.).

\section{Colle di Pianciano series}

Two humified layers (paleosols), respectively at top and base of layered calcitic-fluoritic lacustrine sediment, average thickness $6 \mathrm{~m}$, probably related to late-volcanic hydrothermal activity; interbedded in upper part of La Storta tuff in Sabatini Mts. volcanic region, Colle di Pian-

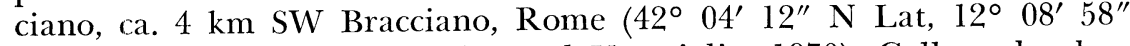
E Long) (Spada, 1969; Mattias and Ventriglia, 1970). Coll. and subm. 1969 by M. Fornaseri, Ist. Geochim., Univ. of Rome.

\section{R-702. Colle di Pianciano 1}

$$
\begin{array}{r}
>\mathbf{4 1 , 0 0 0} \\
\delta \mathrm{C}^{13}=-25.8 \% \text {. }
\end{array}
$$

Humic acids extracted from humified layer at top of calcitic-fluoritic deposit.

\section{R-701. Colle di Pianciano 2}

$28,900 \pm 1300$ 26,950 в.с.

$\delta \mathrm{C}^{13}=-24.1 \%$

Humic acids extracted from humified layer at base of calcitic-fluoritic deposit. Comment: if compared with R-702, age should show probable contamination of lower humified layer by younger humic material. General Comment: samples pretreated with $6 \mathrm{~N} \mathrm{HCl}$; humic acids extracted with $6 \% \mathrm{NH}_{4} \mathrm{OH}$ and precipitated again by dilute $\mathrm{HCl}$. Calciticfluoritic sediment is being studied for correlation with similar sediments from N Rome area (Masi and Turi, 1971). When dating was requested, age of La Storta tuff was unknown. Recently, biotite from latter was dated both by $\mathrm{K} / \mathrm{Ar}$ (Ambrosetti et al., 1969) and fission tracks (Bonadonna and Bigazzi, 1969): its age lies between $0.225 \pm 0.060$ million yr and $0.280 \pm 0.030$ million yr, confirming R-702 date and supposed contamination of R-701.

\section{Campi Flegrei, Napoli}

The following series include a 1st group of systematic dates of carbonized wood and humified layers of paleosols interbedded in pyroclasts of Campi Flegrei volcanic region characterized by numerous volcanic vents and complex deposits of tephra. As well known, the long activity of this volcanic system started presumably in Pliocene (Archiphlegrean) 
(Rittmann et al., 1950) continuing through Pleistocene and historical times (Mt. Nuovo eruption A.D. 1538). Main periods of activity were recognized by De Lorenzo (1904), and redefined by Rittman (1950). Humified layers, sampled chiefly along sections exposed in phlegrean tuff and pozzolana quarries, are mostly interbedded with pyroclasts belonging to well-identified and significant eruptive events, sometimes extending over vast areas. Samples were pretreated with $8 \mathrm{~N} \mathrm{HCl}$; humic acids extracted with $6 \% \mathrm{NH}_{4} \mathrm{OH}$ and precipitated again by dilute $\mathrm{HCl}$. Carbonized wood and humified layers coll. and subm. 1969-1970 by M. Fornaseri, C. Cortesi, and G. Calderoni, Ist. Geochim., Univ. of Rome, and A. Scherillo and E. Franco, Ist. Mineral., Univ. of Naples.

\section{R-567. Cava dell'Arciprete}

\section{1st Phlegrean period}

$\delta \mathrm{C}^{13}=-24.4 \%$
Charcoal, $1.5 \mathrm{~m}$ above base of "Campanian gray tuff" yellow facies, Arciprete quarry, $77.8 \mathrm{~km}$ along state rd. no. 7 bis, prov. Avellino, Campania $\left(40^{\circ} 54^{\prime} 13^{\prime \prime} \mathrm{N}\right.$ Lat, $14^{\circ} 45^{\prime} 12^{\prime \prime} \mathrm{E}$ Long). Comment: sample pretreated with only $5 \%$ HCl because humic charcoal was completely soluble in $6 \% \mathrm{NH}_{4} \mathrm{OH}$.

\section{Cava Crescenzo series}

Carbonized wood and humified layer from Crescenzo tuff quarry, near church of St. Anna, ca. $7 \mathrm{~km} \mathrm{~N}$ Nocera Inferiore, prov. Salerno,

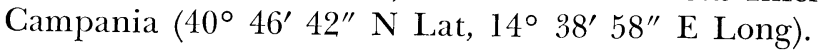

\section{R-565. Cava Crescenzo I-1}

$$
\begin{array}{r}
>\mathbf{4 0 , 0 0 0} \\
\delta \mathrm{C}^{13}=-24.7 \%
\end{array}
$$

Carbonized wood, fragment of little trunk or branch, from pumicelapilli layer, ca. $50 \mathrm{~cm}$ thick, underlying "Campanian gray tuff". Comment: only $2 \% \mathrm{HCl}$ pretreatment because humic charcoal completely soluble in $6 \% \mathrm{NH}_{4} \mathrm{OH}$.

\section{R-577A. Cava Crescenzo I-2}

$33,000 \pm 1400$

31,050 B.C.

$\delta C^{13}=-24.5 \%$

\section{R-716. Cava Crescenzo I-2}

$$
\begin{aligned}
& \mathbf{2 7 , 8 0 0} \pm \mathbf{8 0 0} \\
& \mathbf{2 5 , 8 5 0} \text { в.C. }
\end{aligned}
$$$$
\delta \mathrm{C}^{13}=-24.6 \%
$$

\section{R-716A. Cava Crescenzo I-2}

$29,300 \pm 1000$ 27,350 B.c.

$\delta \mathrm{C}^{13}=-24.9 \%$

Humic acids from humified layer underlying pumice-lapilli layer. Comment: humic acids extracted from samples of same layer coll. at 3 different sites of quarry. Owing to date of overlying R-565 charred wood, contamination of old humified layer by younger humic materials can be inferred. 


\section{R-717. Cava Crescenzo I-2}

Small fragments of charred material from above humified layer and gathered from R-716 and -716A. Comment: thorough separation of charred fragments from humic material was not possible. Sample pretreated with only $5 \% \mathrm{HCl}$ since humic charcoal was completely soluble in $6 \% \mathrm{NH}_{4} \mathrm{OH}$. Contamination by younger humic substances must be assummed.

General Comment on 1st Phlegrean period: dates relate exclusively to the "Campanian gray tuff" or "Campanian ignimbrite," which constitutes the main formation of ancient Phlegrean activity (Ist. Min., Univ. of Naples, 1968). As expected, age, at least in lower part, exceeds limits of our counting system (see R-567 and 565). Dates for underlying humified layer, owing to assumed contamination, are minimum.

Three $\mathrm{K} / \mathrm{Ar}$ dates are available prior to 2nd period: two, measured by Gasparini, $0.22 \pm 0.06$ and $0.19 \pm 0.05$ million yr (Gasparini and Adams, 1969; Givetta et al., 1970), relate to Piperno formation at Torre di Franco, described by Rittmann et al. (1950) underlying Neapolitan yellow tuff of 2nd period. Curtis reported for Sorrento black tuff, belonging to "Companian gray tuff" formation, $\mathrm{K} / \mathrm{Ar}$ age 30,000 yr (Curtis, 1966). Alleged report attributed by this author to A. G. Segre about $\mathrm{C}^{1 \cdot 4}$ date of $35,000 \mathrm{yr}$ measured by Rome lab. is untrue; tuff was not dated by this lab. before now.

\section{2nd Phlegrean period}

Humified layers interbedded in lower pyroclastic units of 2nd period from various localities in E suburb of Naples area (Scherillo and Franco, 1967).

\section{Vallone dei Ponti Rossi quarries series}

Quarries along Ponti Rossi Valley, E suburb of Naples expose tephra of all 3 Phlegrean periods (Scherillo, 1955).

\section{Ponti Rossi Cava Ovest series}

Humified layers with embedded "tasso", local name for a typical guide layer composed by thin interbedded levels of lapilli and pumices, in lower unit of 2nd period from sec. of W quarry, Ponti Rossi Valley,

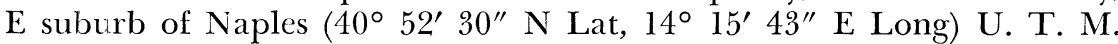
system 33 T VF 379254.

\section{R-584. Ponti Rossi, Cava Ovest II-1}

Humic acids from layer overlying "tasso". 


\section{R-583. Ponti Rossi, Cava Ovest II-2}

Humic acids from layer underlying "tasso".

\section{R-585. Ponti Rossi, Cava Grande II-1}

Humic acids from humified layer overlying "tasso", lower unit of 2nd period in sec. of Cava Grande, close to W quarry, Ponti Rossi valley. Comment: R-583 -585 related to "tasso" are consistent; see also R-705 and -706, this list.

\section{Capodichino, Via F. Provenzale series}

Sec. of relict spur, ca. $4 \mathrm{~m}$, in Via F. Provenzale, crossroad of Calata di Capodichino, E suburb of Naples $\left(40^{\circ} 52^{\prime} 30^{\prime \prime} \mathrm{N}\right.$ Lat, $14^{\circ} 16^{\prime} 04^{\prime \prime}$ E Long) U.T.M. system 33T VF 384 254, shows under vegetal soil, 5 humified layers thought to be interbedded in lower tephra of 2 nd period and perhaps partly underlying them. Only layers 1, 3, and 4 have been dated.

\section{R-580. Via F. Provenzale II-I}

Humic acids from upper Layer 1.

\section{R-581. Via Francesco Provenzale II-3}

Humic acids from intermediate Layer 3.

\section{R-582. Via F. Provenzale II-4}

Humic acids from intermediate Layer 4.

\section{R-578. Capodichino, Cava Alderisio}

Middle humified layer from sec of relict spur, $\mathrm{ca}_{2} 2 \mathrm{~m}$, in Alderisio quarry, Alderisio crossroad of Calata di Capodichino, E suburb of Naples $\left(40^{\circ} 52^{\prime} 13^{\prime \prime} \mathrm{N}\right.$ Lat, $14^{\circ} 16^{\prime} 15^{\prime \prime}$ E Long) U.T.M. system 33T VF 386 249. Sec. exposes 3 humified layers interbedded in pumice of lower units of 2nd period, overlying tephra of 1st period.

\section{Pesole d'Arpino, Cava Masseria Ferrara series}

Secs. in Cava Masseria Ferrara e Jorio, a quarry at Pesole d'Arpino, E suburb of Naples $\left(40^{\circ} 52^{\prime} 57^{\prime \prime} \mathrm{N}\right.$ Lat, $14^{\circ} 17^{\prime} 47^{\prime \prime}$ E Long) U.T.M. system 33T VF 408 262, show products of 3rd and 2nd Phlegrean periods (Scherillo, 1955). 


\section{R-704. Cava Masseria Ferrara II-O}

$$
\begin{gathered}
10,740 \pm 90 \\
\mathbf{8 7 9 0} \text { B.c. } \\
\delta \mathrm{C}^{13}=-26.6 \% 0
\end{gathered}
$$

Humic acids from humified layer underlying Agnano products of 3rd period and overlying upper gray pozzolana of 2nd period; coll. from end sec. of quarry.

\section{R-705. Cava Masseria Ferrara II-2}

$$
\begin{gathered}
11,650 \pm 90 \\
9700 \text { в.с. }
\end{gathered}
$$

Humic acids from humified layer underlying "tasso"; sample coll. $\mathrm{S}$ side of spur in W sec. of quarry. Comment: see R-706, below.

\section{R-706. Cava Masseria Ferrara II-2}

$$
\begin{gathered}
11, \mathbf{8 0 0} \pm \mathbf{1 0 0} \\
\mathbf{9 8 5 0} \text { B.C. } \\
\delta \mathrm{C}^{13}=-25.7 \% 0
\end{gathered}
$$

Humic acids from humified layer underlying "tasso" coll. $\mathrm{N}$ side of spur in W sec. of quarry. Comment: R-705 and -706 agree with ages of humified layers related to "tasso" coll. in secs. of Ponti Rossi quarries (see R-583 -585, this list).

General Comment on 2nd Phlegrean period: dates referring to humified layers interbedded in lower pyroclasts of 2nd period are consistent and date back its early eruptive activity from 12,800 to 11,600 B.P. R-704 is referred to upper part of gray pozzolana of 2nd period and is, therefore, consistent with ages of lower part. This date also agrees with one for Neapolitan yellow tuff, most widespread product of main phase of 2nd period (Scherillo, 1950): Pi-75, 10,090 \pm 215 (R., 1961, v. 3, p. 104; Lucini and Tongiorgi, 1959); measurements were made on calcareous fossil wood from facies of Neapolitan yellow tuff during drilling of tunnel through Vomero, Naples.

\section{$3 r d$ Phlegrean period}

To the 3rd period of Phlegrean activity belong many recognizable vents, e.g., volcanoes of Agnano, Solfatara, Averno, Astroni, Senga, the most recent being Monte Nuovo of historic age. Field observations indicate some well-ascertained sequences of activity but a general relative chronology cannot be established. Palethnologic evidence, from potsherds found in humified layer underlying Astroni ash places eruption after Eneolithic (Perozzi, 1949). Senga eruption, younger than Astroni but still prehistoric, could be between 1500 and 400 B.c. Many humified layers are interbedded in pyroclasts of 3 rd period.

\section{R-703. Cava Masseria Ferrara III-1}

$4360 \pm 50$

2410 B.c.

$\delta \mathrm{C}^{13}=-25.4 \%$ o

Humic acids from humified layer underlying pumice of Astroni volcano, upper part of 3rd period in quarry at Pesole d'Arpino, E suburb 
of Naples (see also Pesole d'Arpino series, Phlegrean 2nd period). Comment: sample coll. at end sec. of quarry. Date is consistent with other humified layers underlying Astroni products (see R-596 and 592, this list).

\section{R-682. Via Terracina, Napoli}

$4000 \pm 50$ 2050 B.C.

Carbonized wood from small outcrop of pozzolana and pumice at Via Terracina, Nuovo Rione S. Paolo, W suburb of Naples $\left(40^{\circ} 50^{\prime}\right.$ $22^{\prime \prime} \mathrm{N}$ Lat, $14^{\circ} 11^{\prime} 12^{\prime \prime}$ E Long) U.T.M. system 33T VF 315 215. Comment: provenance of formation doubtful; date suggests Astroni volcano.

\section{R-708 $\alpha$. Astroni}

$3520 \pm 50$

1570 B.C.

$\delta \mathrm{C}^{13}=-23.9 \%$

Carbonized wood, fragment of small trunk or branch, from pumice and pozzolana quarry in $\mathrm{N}$ side of well-preserved Astroni crater, Campi Flegrei $\left(40^{\circ} 51^{\prime} 15^{\prime \prime} \mathrm{N}\right.$ Lat, $14^{\circ} 08^{\prime} 50^{\prime \prime}$ E Long) U.T.M. system $33 \mathrm{~T}$ VF 282 232. Comment: carbonized wood is scattered through Astroni products. Another carbonized branch from Astroni crater pyroclasts dated at Gif lab., unnumbered sample, $3950 \pm 120$ (Delibrias et al., 1969).

\section{Shione Mofete, Trattoria del Tedesco series}

Road cut, ca. $200 \mathrm{~m}$ from Trattoria del Tedesco upward, Rione

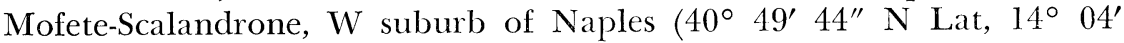
33" E Long) U.T.M. system 33T VF 221 204, reveals 4 humified layers.

\section{$3700 \pm 50$ \\ R-591. Rione Mofete, Trattoria del Tedesco III-1 1750 B.c. $\delta \mathrm{C}^{13}=-25.7 \%$}

Humic acids from upper Layer 1 between Averno and Astroni (?) products. Comment: $\mathrm{C}^{14}$ age could confirm attribution to Astroni of underlying layer (see also R-597, this list).

\section{$4520 \pm 50$ \\ R-592. Rione Mofete, Trattoria del Tedesco III-2 2700 B.c.$$
\delta \mathrm{C}^{13}=-26.2 \%
$$

Humic acids from intermediate Layer 2 underlying Astroni (?) cinder layer. Comment: $\mathrm{C}^{14}$ date is consistent with Astroni date of overlying layer (see also R-596 and R-703, this list).

\section{R-593. Rione Mofete, Trattoria del Tedesco III-3 $\quad \mathbf{5 2 7 0} \pm \mathbf{5 3 0}$ $\delta \mathrm{C}^{13}=-25.9 \%$}

Humic acids from intermediate Layer 3 overlying yellow unconsolidated tuff. 


\section{R-594. Rione Mofete, Trattoria del Tedesco III-4 $6450 \pm 70$

Humic acids from lower Layer 4 overlying yellow consolidated tuff. Comment: date is oldest available for products of 3rd period.

\section{R-595. Rione Mofete, Villa Jannon}

$5880 \pm 50$

3930 B.C.

$\delta \mathrm{C}^{13}=-24.1 \%$

Humic acids from lower of 2 humified layers in quarry at Villa Jannon, Rione Mofete, W suburb of Naples $\left(40^{\circ} 49^{\prime} 27^{\prime \prime}\right.$ N Lat, $14^{\circ}$ 04' 17" E Long) U.T.M. system 33T VF 218 199. Comment: 2 humified layers are interbedded in pyroclasts of doubtful provenance. Date compares with R-593 humified layer in Trattoria del Tedesco series.

\section{Bivio di Quarto series}

Sec. ca. $4 \mathrm{~m}$, at junction of Domiziana and Quarto Rds., W Naples $\left(40^{\circ} 51^{\prime} 01^{\prime \prime} \mathrm{N}\right.$ Lat, $14^{\circ} 04^{\prime} 18^{\prime \prime} \mathrm{E}$ Long) U.T.M. system 33T VF 218 228, reveals 2 humified layers.

\section{R-597. Bivio di Quarto III-1}

$3820 \pm 50$ 1870 B.C.

Humic acids from upper Layer between Averno and Astroni (?) products. Comment: $\mathrm{C}^{14}$ age could confirm attribution to Astroni volcano of underlying layer (see also R-591, this list).

\section{R-596. Bivio di Quarto III-2}

Humic acids from lower Layer underlying Astoni Comment: $\mathrm{C}^{14}$ age is consistent Comment: $\mathrm{C}^{14}$ age is consistent with Astroni date of overlying layer (see also R-592 and R-703, this list).

General Comment on 3rd Phlegrean period: dates range from 3500 to 8500 i.P. Carbonized wood in Astroni products place eruptions between 3500 and 4000 B.P. (R-682, R-708 $\alpha$, and Gif samples). Humified layers correlated with Astroni products show consistent ages (R-591, R-597) as do humified layers underlying Astroni products (R-592, R-596, and $\mathrm{R}-703)$. In Rione Mofete series, products of 3rd period whose provenance has not yet fully established date back to ca. 8500 B.P. (R-591-R-594).

\section{REFERENCES}

Alessio, M., Bella, F., Bachechi, F., and Cortesi, C., 1967, University of Rome carbon14 dates V: Radiocarbon, v. 9, p. 346-367.

Alessio, M., Bella, F., and Cortesi, C., 1964, University of Rome carbon-14 dates II: Radiccarbon, v. 6, p. 77-90.

Alessio, M., Bella, F., Cortesi, C., and Graziadei, B., 1968, University of Rome carbon14 dates VI: Radiocarbon, v. 10, p. 350-364.

Alessio, M., Bella, F., Cortesi, C., and Turi, B., 1969, University of Rome carbon-14 dates VII: Radiocarbon, v. 11, p. $482-498$.

Alessio, M., Bella, F., Improta, S., Belluomini, G., Cortesi, C., and Turi, B., 1970, Report on the equipments and the activities of Rome University's carbon-14 dating laboratory: Quaternaria, v. 13, p. 357-376. 
Ambrosetti, P., Bonadonna, F. P., and Tolomeo, L., 1969, Studi sul Pleistocene deI Lazio. VI-Una nuova data per la Campagna Romana: Soc. Geol. Italiana Boll., v. 88 , p. $3-10$.

Atzeni, E., 1967, Tombe a forno di cultura Monte Claro nella Via Basilicata di Carliari: Riv, Sci. Preistoriche, v. 22, p. 177-178.

Barfield, L. H., 1968, Una nuova datazione assoluta per la stazione di Molina di Ledro-Considerazioni sulla cronologia della cultura di Polada: Riv. Sci. Preistoriche, v. 23, p. 261-263.

Battaglia, R., 1943, La palafitta di Ledro nel Trentino: Mus. Storia naturale della Venezia Tridentina Mem., v. 7, p. 3-63.

Bonadonna, F. P. and Bigazzi, G., 1969, Studi sul Pleistocene del Lazio. VII-Età di un livello tufaceo del bacino diatomitico di Riano stabilita con il metodo delle tracce di fissione: Soc. Geol. Italiana Boll., v. 88, p. 439-444.

Bray, W., 1963, The Ozieri culture of Sardinia: Riv. Sci. Preistoriche, v. 18, p. 155-190.

Caputo, G., 1961, La tradizione etrusca del Grifo e l'emblema di Perugia: Studi Etruschi, v. 29, p. 417-422.

Castaldi, E., 1971, Considerazioni su una datazione con il carbonio-14 della Grotta del Guano o di Gonogusola, ms. in preparation.

Cellini, Benvenuto, 1568, Intorno alle otto principali arti dell'Oreficeria e in materia dell'arte della Scultura, trattati due: Firenze, Panizzi e Peri.

Civetta, L., Gasparini, P., and Adams, J. A. S., 1970, Geochronology and geochemical trends of volcanic rocks from Campania S Italy: Eclogae geol. Helveticae, v. 63, p. 63-68.

Contu, E., 1964, Grotta del Guano (Oliena): Riv. Sci. Preistoriche, v. 19, p. 316.

Contu, E., 1964, Grotta del Guano (Oliena): Riv. Sci. Preistoriche, v. 21, p. 434. 1966, Grotta del Guano (Oliena): Riv. Sci. Preistoriche, v. 21, p.

Cornaggia Castiglioni, O., 1967, Quattro eccezionali bronzi preistorici italiani: i diademi enei di Molina di Ledro nel Trentino: Riv. Sci Preistoriche, v. 22, p. $181-267$.

Coursaget, J. and Le Run, J., 1966, Gif-sur-Yvette natural radiocarbon measurements I: Radiocarbon, v. 8, p. 128-141.

Cremonesi, G., 1965, Il villaggio di Ripoli alla luce dei recenti scavi: Riv. Sci. Preistoriche, v. 20, p. 85-155.

1967, I materiali provenienti dal territorio di Vho conservati nel Museo Civico di Cremona: Soc. Toscana Sci. Nat. Mem. Atti, v. 74, p. 375-409.

Curtis, G. H., 1966, The problem of contamination in obtaining accurate dates of young geologic rocks, in: Shaeffer, O. A. and Zähringer, J. (eds.), Potassium argon dating, Berlin, Springer.

Delibrias, G., Guillier, M. T., and Labeyrie, J., 1970, Gif natural radiocarbon measurements V: Radiocarbon, v. 12, p. 421-443.

Delibrias, G., Kieffer, G., and Pelletier, H., 1969, Datation par la méthode du carbon14 de l'Astroni, volcan des Champs Phlégréens (Campanie): Acad. sci. [Paris] Comptes rendus, v. 269, p. 2070-2071.

De Lorenzo, G., 1904, L'attività vulcanica dei Campi Flegrei: Accad. Sci. Fis. e Mat. Rend., Napoli, s. 3, v. 10, p. 203-221.

Ferrara, G., Fornaca-Rinaldi, G., and Tongiorgi, E., 1961, Carbon-14 dating in Pisa-II: Radiocarbon, v. 3, p. 99-104.

Ferrarese Ceruti, M. L., 1967, Domus de Janas in località Molimentos (BenetuttiSassari): Paletnol. Italiana Bull., n.s. 18, v. 76, p. 96-97.

Ferri-Ricchi, L., 1969, Come nuova l'oneraria dell'Elba: Mondo Sommerso, v. 11, p. $989-995$.

Fioravanti, A. and Ferri-Ricchi, L., 1970, Naufragio all'Elba: Atlante, v. 11, no. 62,

p. 76-83.
Gasparini, P. and Adams, J. A. S., 1969, K/Ar dating of Italian Plio-Pleistocene volcanic rocks: Earth and Planetary Sci. Letters, v. 6, p. 225-230.

Govi, G., 1967, Identificazione del legno di palafitte nella necropli di Spina: Natura e Montagna, s. 3, v. 7, no. 1-2, p. 60-62.

Guerreschi, G., 1967, La Lagozza di Besnate e il Neolitico superiore padano: Como, Tipografia A. Noscola.

Ist. Mineralogia, Univ. di Napoli, 1968, La pianura campana e il suo tufo: XXV congr. Soc. Italiana di Mineral. e Petrol., Naples, 7-11 Oct. 1968.

Lawn, Barbara, 1970, University of Pennsylvania radiocarbon dates XIII: Radiocarbon, v. 12 , p. $577-589$.

Lilliu, G., 1967, La civiltà dei Sardi dal Neolitico all'età dei Nuraghi: ERI-Ed. RAI, Radio televisione italiana, 2nd ed., Torino. 
Lollini, D., 1961, Ancarano di Sirolo: Riv. Sci Preistoriche, v. 16, p. 268.

Lona, F., 1957, I depositi lacustri Euganei, archivio paleontologico del tardo glaciale e del periodo postglaciale: Biogeog. Adriatica Mem., v. 5, p. 1-11.

Lucini, P. and Tongiorgi, E., 1959, Determinazione con il carbonio-14 di un legno fossile dei Campi Flegrei (Napoli): Studi e Ricerche della Div. Geomineraria C.N.E.N., v. 2, p. $97-99$

Marabelli, M., 1971, Esami chimici e mineralogici riguardanti il Grifo e il Leone ormanti il portale del Palazzo dei Priori di Perugia: ms. in preparation.

Marchesoni, V., 1959, Ricerche pollinologiche in sedimenti torbosi della Pianura Padana: Nuovo Gior. Bot. Italiano, n.s., v. 66, p. 336-339.

Marchesoni, V. and Paganelli, A., 1966, Tavola cronologica del Quaternario: Studi Trentini di Sci. Nat., s. B, v. 43, p. 79-188.

Masi, U. and Turi, B., 1971, La composizione isotopica dell'ossigeno e del carbonio del carbonato presente nei depositi calcitico-fluoritici pleistocenici dei Colli della Farnesina (Roma) e di Colle di Pianciano (Bracciano): Periodico di Mineral., in press.

Mattias, P. P. and Ventriglia, U., 1970, La regione vulcanica dei Monti Sabatini e Cimini: Soc. Geol. Italiana Mem., v. 9, p. 331-384.

Mohen, J. P., 1967, Notes préliminaires à propos des fouilles du camp néolithique de "Chez Reine" commune de Semussac (Charente-Maritime): Soc. préhistorique francaise Bull., v. 64, p. 469-482.

Montanari, F. L., 1969, Lineamenti della vegetazione del litorale Ferrarese e Ravennate: Natura e Montagna, s. 3, v. 9, no. 4, p. 25-34.

Parazzi, A. 1891, Stazione dei Lagazzi fra Vho e S. Lorenzo Guazzone: Paletn. Ital. Bull., v. 18, p. 1-33

Perozzi, A., 1949, Ritrovamento di resti dell'Eneolitico in provincia di Napoli: Ricerca Sci., v. 19 , p. 1025 .

Pinna, G. 1966-1967, Statuina fittile di Dea Madre de Puisteris (Mogoro-Cagliari): Studi Sardi, v. 20, p. 68-73.

Radmilli, A. M., 1967, Isola di Pantelleria: Riv. Sci. Preistoriche, v. 22, p. 452.

Rittmann, A. et al., 1950, Rilievo geologico dei Campi Flegrei: Soc. Geol. Italiana Boll., v. 69 , p. 117-362.

Scherillo, A., 1950, Petrografia chimica dei tufi flegrei. I-Il tufo giallo: Accad. Sci. Fis. e Mat. Rend. della Soc. Naz. di Sci. Lettere e Arti di Napoli, s. 4, v. 17, p. $343-356$.

1955. Petrografia chimica dei tufi flegrei. II-Tufo giallo, mappamonte, pozzolana: Accad. Sci. Fis. e Mat. Rend. della Soc. Naz. di Sci., Lettere e Arti di Napoli, s. 4, v. 22, p. 345-370.

Scherillo, A and Franco, E., 1967, Introduzione alla carta stratigrafica del suolo di Napoli: Accad. Pontaniana Atti, n.s., v. 26, p. 27-38.

Shotton, F. W., Blundell, D. J., and Williams, R. E. G., 1968, Birmingham University radio

Spada, A., 1969, Il giacimento di fluorite e baritina esalativo-sedimentario in "facies" lacustre intercalato nei sedimenti piroclastici della zona di Castel Giuliano in prov di Roma: Industria Mineraria, s. 2, v. 20, p. 501-518.

Stampi, P., 1966, Le antiche selve che vegetavano sul litorale ferrarese (Nota preventiva): Bot. Italiano Gior., v. 73, p. 337-339. ventiva): Bot. Italiano Gior., ve 1967 , Il gran bosco della Mesola (Ferrara): notizie storiche, floristiche e geobotaniche: Annali Bot., v. 28, p. 599-612.

Stuckenrath, R. Jr. Coe, W. R., and Ralph, E. K., 1966, University of Pennsylvania radiocarbon dates IX: Radiocarbon, v. 8, p. 348-385.

Theophilus, 1140?, De diversis artibus, Nelson's Medieval Tests, 1961.

Thomas, H. F., 1965, The archaeological chronology of Northwestern Europe, in Ehrich, R. W. (ed.), Chronologies of old world archaeology: Chicago, University of Chicago Press.

Tozzi C.. 1968, Relazione preliminare sulla I e II campagna di scavi a Pantelleria: Riv Sci. Preistoriche, v. 23, p. 315-388.

Vannoccio Biringuccio, 1540, De Pirotechnia, Venezia.

Vasari, Giorgio, 1568, Le vite de' più eccellenti pittori, scultori e architetti: Giunti, Firenze, 2nd ed. 